\title{
Studi Kasus Program CSR PT. Pertamina RU II Sungai Pakning pada Program Revitalisasi Kawasan Mangrove di Provinsi Riau
}

\author{
Asri Dewi a,1,* dan Yeni Rosilawati ${ }^{\mathrm{b}, 2}$ \\ a,bUniversitas Muhammadiyah Yogyakarta \\ Email: 1asridewi.tbh@gmail.com*dan²yenirosilawati@gmail.com \\ *corresponding author
}

\section{Keywords:}

$C S R$, environmental conservation, community empowerment, revitalization, mangrove

\section{Kata Kunci:}

csr, konservasi lingkungan, pemberdayaan masyarakat, revitalisasi, mangrove

\begin{abstract}
The company's contribution to building society is implemented through the Corporate Social Responsibility program, known as the CSR program. The concept of CSR is influenced by the idea that the existence of a company depends on the life of the environment and the community in which it lives and is adjusted to the problems that exist around the company's location as a form of responsibility to the stakeholders and the surrounding environment. This study aims to describe the implementation of an environmental conservationbased CSR program carried out by PT Pertamina RU II Sungai Pakning. This study uses a qualitative paradigm while the data in this study were collected through in-depth interviews with local communities, local community leaders, CDOs, and CSR coordinators who are directly responsible for CSR programs. Besides, the secondary data was obtained through the company's website, CSR reports, and news in the mass media about the CSR of PT Pertamina RU II Pakning. The results of this study indicate that the environmentalbased CSR program is implemented through a Mangrove conservation and revitalization program through community empowerment. Local people are actively involved in handling environmental issues through working groups on conservation and revitalization of Mangrove areas, cultivation of brackish fish, and product processing.
\end{abstract}

\begin{abstract}
ABSTRAK
Kontribusi perusahaan dalam membangun masyarakat diwujudkan melalui program Corporate Social Responsibility yang dikenal dengan program CSR. Konsep CSR dipengaruhi oleh pemikiran bahwa keberadaan perusahaan bergantung pada kehidupan lingkungan dan masyarakat di mana perusahaan tersebut hidup dan disesuaikan dengan permasalahan yang ada disekitar lokasi perusahaan sebagai bentuk tanggung jawab kepada stakeholders dan lingkungan sekitarnya. Penelitian ini bertujuan untuk mendeskripsikan implementasi program CSR berbasis pelestarian lingkungan yang dilakukan oleh PT Pertamina RU II Sungai Pakning. Penelitian ini menggunakan paradigma kualitatif sedangkan data dalam penelitian ini dikumpulkan melalui wawancara mendalam dengan masyarakat lokal, tokoh masyarakat setempat, $\mathrm{CDO}$, dan koordinator CSR yang bertanggung jawab langsung atas program CSR. Selain itu, data sekunder diperoleh melalui website perusahaan, laporan CSR, dan berita di media massa tentang CSR PT Pertamina RU II Pakning. Hasil penelitian ini menunjukkan bahwa program CSR berbasis lingkungan dilaksanakan melalui program konservasi dan revitalisasi Mangrove melalui pemberdayaan masyarakat. Masyarakat setempat terlibat aktif dalam penanganan masalah lingkungan melalui kelompok kerja konservasi dan revitalisasi kawasan Mangrove, budidaya ikan payau, dan pengolahan produk.
\end{abstract}

Copyright (C) 2020 Channel Jurnal Komunikasi. All right reserved. 


\section{PENDAHULUAN}

Perkembangan dunia di berbagai bidang seperti industri, teknologi, maupun infrastruktur mengakibatkan dampak lingkungan yang terjadi semakin banyak. Usaha dalam meningkatkan kesejahteraan hidup yang diidentifikasi dengan tingkat ekonomi dan pendapatan ternyata tidak berjalan seiring dengan kondisi lingkungan yang semakin parah. Akibatnya adalah ketidakmampuan masyarakat untuk dapat hidup secara berkelanjutan dalam usaha meningkatkan ekonomi sekaligus memelihara lingkungan (Rudito dan Famiola, 2013).

Kontribusi perusahaan dalam membangun masyarakat diterapkan melalui program Tanggung Jawab Sosial Perusahaan atau lebih dikenal dengan Corporate Social Responsibility (CSR). Di antara banyak definisi tanggung jawab sosial perusahaan, yang paling banyak diterima saat ini adalah bahwa,

“Kontribusi sukarela perusahaan untuk pembangunan berkelanjutan” (Lamarche, 2018).

Dalam hal ini, perusahaan tidak hanya memiliki kewajiban untuk melakukan program tanggung jawab kepada masyarakat, namun untuk memastikan dampak dan manfaat yang didapatkan masyarakat melalui program itu berkelanjutan (sustainability). Pelaksanaan program CSR juga meningkatkan hubungan perusahaan dengan masyarakat sekitar, atau dikenal melalui praktik hubungan komunitas atau biasa disebut dengan community relations. Komunitas dipahami sebagai sekelompok orang yang memiliki kepentingan dan terkait dengan keberadaan perusahaan, serta secara geografis berada di wilayah sekitar perusahaan (Grunig dan Hunt, 1984). Aktivitas perusahaan terutama pengelola sumber daya alam yang tidak dapat diperbaharui seperti minyak bumi dan gas serta pertambangan memiliki dampak lingkungan yang besar seperti limbah, polusi, rusaknya infrastruktur umum, hingga kebisingan yang diakibatkan oleh aktivitas mesin. Hubungan antara perusahaan dan masyarakat berperan dalam pertahanan lingkungan yang mana baik perusahaan dan komunitas dapat bekerja sama dalam pelestarian lingkungan, di sisi lain dapat menjaga relasi antara kedua belah pihak.

Konsep CSR dipengaruhi pemikiran bahwa keberadaan perusahaan bergantung hidup dari lingkungan dan masyarakat di mana dia berada. Kegiatan CSR harus disesuaikan dengan permasalahan yang ada pada sekitar lokasi perusahaan sebagai bentuk tanggung jawab kepada para stakeholders dan lingkungannya (Rosilawati dan Mulawarman, 2019). Lo dan Sheu (2007) mengatakan bahwa tindakan yang tidak beretika yang dilakukan oleh perusahaan terhadap pemangku kepentingan di masa depan mempengaruhi potensi keuntungan mereka yang akan didapatkan. Konsep seperti etika perniagaan dan CSR, di mana 30 tahun yang lalu tidak terdapat dalam kosa kata, maka saat ini menjadi topik dalam dokumen-dokumen perusahaan, rencana strategik dan laporan tahunan (Mostardeiro \& Duarte, 2007).

Perusahaan juga mendapatkan tantangan untuk menerapkan prinsip-prinsip etika bisnis dan CSR dalam pengambilan keputusan mereka. CSR juga semakin dipandang penting dalam meningkatkan dan memelihara reputasi korporat serta dipandang sebagai strategi komprehensif dalam perusahaan yang berorientasi pada pemegang kepentingan (Silberhorn \& Warren, 2007). Tidak hanya menyelesaikan tanggung jawab sosial yang memungkinkan organisasi untuk menunjukkan tingkat moral atau perilaku etis mereka yang tinggi, tetapi juga telah terbukti memberi mereka manfaat instrumental dan berbagai jenis keunggulan kompetitif. Mencakup hal-hal seperti kinerja keuangan yang unggul, reputasi yang meningkat, tenaga kerja yang lebih termotivasi, dan kemampuan untuk menarik karyawan yang diinginkan (Salim, 2018). Perusahaan juga harus memperhatikan dampak dari program pembangunan berkelanjutan yang memiliki kebijakan pembangunan sosial, pembangunan ekonomi, dan perlindungan lingkungan yaitu konsep Triple Bottom Line (TBL) (Untung, 2008). Konsep ini menyatakan bahwa, jika perusahaan ingin sustain maka perusahaan harus memperhatikan aspek 3P (People, Planet, Profit) karena pada dasarnya pembangunan berkelanjutan tidak dapat dilihat dari satu aspek saja.

Menjalankan bisnis dalam perspektifCSR berarti bahwa para pelaku bisnis bertindak lebih beretika dan bertanggung jawab terhadap berbagai pemangku kepentingan dan masyarakat. Di Indonesia, terdapat beberapa kasus perusahaan yang berhubungan dengan persoalan CSR. Kerusakan lingkungan yang parah serta praktek bisnis yang tidak beretika yang dilakukan oleh perusahaan yang memberikan dampak buruk tidak hanya kepada masyarakat namun juga membuat perusahaan kehilangan reputasi. Pengelolaan CSR diperlukan karena akan menimbulkan manfaat bagi perusahaan dan para pemangku kepentingan. CSR diperlukan untuk perusahaan untuk melampaui kewajiban ekonomi dan hukum mereka dan bertindak secara bertanggung jawab terhadap berbagai pemangku kepentingan termasuk masyarakat. Berbeda dengan negara-negara Anglo Saxon di mana kesadaran untuk melakukan CSR sudah demikian tinggi, di Indonesia CSR masih diatur dalam produk undang-undang sebagai payung hukumnya (Untung, 2008).

CSR diatur melalui UU No 40/2007 Pasal 74 tentang Perseroan Terbatas. Dalam ayat (1) Undang-Undang Perseroan Terbatas tersebut menyatakan perseroan yang menjalankan kegiatan usaha di bidang dan atau berkaitan dengan sumber daya alam wajib melaksanakan tanggung jawab sosial dan lingkungan. Inilah yang dimaksud dengan CSR. Ayat (2) berbunyi tanggung jawab sosial dan lingkungan itu merupakan kewajiban perseroan yang dianggarkan dan diperhitungkan sebagai biaya perseroan yang pelaksanaannya dilakukan dengan memperhatikan kepatutan dan kewajaran. Dalam ayat (3) Undang-Undang Perseroan Terbatas menyatakan bahwa perseroan yang tidak melaksanakan melaksanakan kewajiban sebagaimana dimaksud dalam Pasal 1, dikenakan sanksi sesuai dengan ketentuan peraturan perundang-undangan. Dalam ayat (4) menyatakan ketentuan lebih lanjut mengenai tanggung jawab lingkungan dan diatur oleh peraturan pemerintah. 
Menjalankan bisnis dengan perspektif CSR berarti bahwa para pelaku bisnis bertindak dengan beretika dan bertanggung jawab terhadap pemangku kepentingan (stakeholders). Perusahaan harus memperhatikan aspek sosial di samping segi keuangan. Penekanan yang hanya melibatkan pada segi pengukuran ekonomi saja dapat mengakibatkan petaka pada lingkungan dan masyarakat (Hadi, 2014). CSR mencerminkan pandangan sosio-ekonomi. Perusahaan tidak hanya bertanggung jawab kepada pemilik modal tetapi dapat juga bertanggung jawab kepada masyarakat secara luas (Robbins \& Coulter, 2010; Donaldson \& Preston, 1995, Freeman, 1984).

Di Indonesia CSR relatif berjalan lancar dan diwujudkan secara beragam dan disesuaikan dengan pemegang kepentingannya. Bentuk-bentuk inisiatif CSR di Indonesia beragam dan diwujudkan antara lain dalam bentuk penguatan pelayanan pendidikan, kesehatan serta pelatihan, kampanye lingkungan, penanaman pohon, pembuatan ruang terbuka hijau dan taman, penghematan sumber daya alam yang digunakan di pabrik-pabrik atau toko, penerapan daur ulang dan penggunaan kembali produk (reduce-reuse-recycle) Demikian pula program yang berdampak positif bagi peningkatan kualitas hidup, mata pencaharian dan kemandirian masyarakat dan juga adanya sistem perlindungan sosial terhadap kelompok-kelompok rentan, termasuk penghargaan terhadap kearifan lokal (Rosilawati dan Ahmad, 2019).

Isu lingkungan dan konservasi sumber daya alam merupakan pesan CSR kategori pengungkapan lingkungan yang paling banyak dikomunikasikan pada official website perusahaan BUMN yaitu sebanyak 37 perusahaan (67,3\%) menampilkan isu lingkungan pada official website perusahaan dan sebanyak $37(67,3 \%)$ perusahaan yang diteliti mengkomunikasikan kegiatan CSR yang berhubungan dengan konservasi sumber daya alam (Nurjannah dkk, 2017). Program konservasi sumber daya alam yang banyak dikomunikasikan perusahaan BUMN pada laman resminya adalah program konservasi keanekaragaman hayati seperti penghijauan, pembuatan dan penanaman terumbu karang serta konservasi hewan langka. Salah satu perusahaan yang melaksanakan program CSR adalah Pertamina.

Perusahaan BUMN (Badan Usaha Milik Negara) ini bergerak di bidang penyediaan gas dan minyak bumi. Sebagai perusahaan BUMN, Pertamina berperan besar dalam pelayanan publik dan penyelesaian isu-isu yang berkembang di masyarakat khususnya terkait lingkungan, sosial, dan ekonomi. Pertamina telah melaksanakan kegiatan CSR sejak lama di berbagai provinsi baik terkait isu lingkungan hingga sosial. Komitmen Pertamina dalam melaksanakan tanggung jawab sosial perusahaan diwujudkan dalam berbagai kegiatan CSR yang meliputi bidang pendidikan, kesehatan, lingkungan, infrastruktur, pemberdayaan masyarakat, manajemen bencana, maupun bantuan khusus. Realisasi kegiatan dilaksanakan oleh seluruh unit kerja fungsi CSR Pertamina, baik di kantor pusat, unit operasi, maupun anak perusahaan. Pertamina mengimplementasikan program CSR untuk tujuan People, Planet, dan Profit (3P) (pertamina.com, n.d.). Tujuan ini menjadi fokus Pertamina dalam menjalankan operasionalnya, di mana produk-produk yang dikembangkan dan jasa yang diberikan khususnya terhadap kelestarian lingkungan untuk kepentingan dan masa depan generasi yang akan datang. CSR Pertamina berfokus pada empat isu yang menjadi pilarnya yaitu Pertamina Cerdas, Pertamina Sehati, Pertamina Berdikari, dan Pertamina Hijau.

Program CSR Pertamina Hijau merupakan program konservasi lingkungan yang berfokus kepada pelestarian mangrove. Program ini merupakan program pusat yang dilaksanakan oleh seluruh unit operasi dan anak perusahaan PT. Pertamina. Salah satu unit PT. Pertamina yang melaksanakan program Pertamina Hijau adalah PT. Pertamina RU II Sungai Pakning melalui program Konservasi dan Revitalisasi Kawasan Mangrove Permata Hijau yang berlokasi di Desa Pangkalan Jambi, Kecamatan Bukit Batu, Kabupaten Bengkalis, Provinsi Riau.

Indonesia memiliki mangrove terluas di dunia yaitu 3,4 juta hektar, namun di tahun 2018, sekitar 41 persen atau seluas 1,82 juta ha mangrove berada dalam kondisi kritis. Ekosistem Mangrove merupakan salah satu ekosistem lahan basah yang paling produktif, dengan $80 \%$ tangkapan perairan laut sangat bergantung langsung maupun tak langsung terhadap keberadaan Mangrove dan ekosistem pesisir lainnya (kehati.or.id, n.d.). Aktivitas mesin perusahaan yang selain berdampak limbah lingkungan, juga memiliki dampak terhadap polusi dan pemanasan global.

PT. Pertamina RU II Sungai Pakning juga mendapat Indonesian Sustainable Development Goals Award (ISDA) 2018 untuk poin Sustainable Development Goals (SDGs) 14 tentang Pelestarian Ekosistem Laut (pertamina.com, n.d.). Program Konservasi dan Revitalisasi Mangrove Permata Hijau ini berbeda dengan program CSR perusahaan lain karena dilatarbelakangi isu yang berdampak secara langsung bagi kehidupan masyarakat. Seperti halnya Pertamina, PT Indocement juga melaksanakan program CSR berbasis konservasi mangrove yang dilaksanakan di desa Langadai, Tarjun. Keberadaan Hutan Mangrove di Desa Langadai terancam karena hutan tersebut ditebang untuk menjadi kayu bakar atau dibuka menjadi tambang oleh masyarakat sekitar, tindakan penebangan tersebut memberikan dampak negatif ke masyarakat. Menipisnya ekosistem mangrove akibat penebangan liar, juga karena abrasi lahan parah yang mengakibatkan masyarakat harus relokasi dari tempat tinggal mereka yang semula di pesisir pantai, ke daerah daratan yang lebih jauh merupakan latar belakang dari program CSR tersebut.

\section{TINJAUAN PUSTAKA \\ A. Konsep CSR}

Wacana mengenai CSR lahir dilandasi pemikiran bahwa keberadaan perusahaan tidak dapat dilepaskan dari 
lingkungan dan masyarakat disekitarnya. Perusahaan sebagai institusi sosial pada dasarnya memiliki ketergantungan hidup dari lingkungan dan masyarakatnya. Menurut Daft (2006) definisi CSR merupakan kewajiban manajemen untuk membuat pilihan dan mengambil tindakan yang akan memberikan kontribusi terhadap kesejahteraan dan kepentingan masyarakat serta organisasi itu sendiri.

Sedangkan definisi CSR menurut World Business Council for Sustainable Development (WBCSD, 2002),

"As a commitment to contribute to the sustainable economic development, to work with the company's employees, employee's family'members, local community members and community in general as the efforts of improving the quality of life"

Menurut definisi WBCSD (2002) CSR merupakan komitmen untuk memberikan kontribusi kepada pembangunan berkelanjutan (Sustainable Development) dan bertujuan untuk meningkatkan kualitas hidup masyarakat. Menurut Robbins dan Coulter (2002) definisi CSR adalah,

"A business firm's obligation, beyond that required by law and economics, to pursue long term goals that are good for society. Also note for the definition views business as a moral agent. In its effort to do good for society, it must differentiate between right and wrong “"

Implementasi program CSR dilaksanakan melalui beberapa tahap. Adapun langkah-langkah implementasi CSR (Wibisono, 2007) adalah:

1. Perencanaan. Tahap ini terdiri dari 3 langkah utama yaitu Awareness Building, CSR Assesment, dan CSR Manual Building.

a. Awareness building

Pada tahapan ini bertujuan untuk membentuk kesadaran tentang pentingnya sebuah CSR serta komitmen manajemen perusahaan. Untuk mewujudkan awareness building tersebut dapat dilakukan melalui seminar serta diskusi dengan kelompok.

b. CSR Assesment

Pada tahap CSR assessment berfungsi untuk memetakan bagaimana kondisi perusahaan. Pemetaan tesebut meliputi aspek yang menjadi prioritas perusahaan serta penentuan langkah yang akan diambil ketika akan menerapkan program CSR.

c. $h h$

Pada bagian ini merupakan bagian inti dari tahap perencanaan. CSR manual building merupakan sebuah acuan yang akan digunakan oleh perusahaan yang berisi tentang pedoman serta panduan dalam pelaksanaan kegiatan sosial masyarakat. Pedoman ini juga diharapkan mampu menjadi acuan bagi seluruh tindakan perusahaan agar pelaksanaan program yang bersifat terpadu, efisien dan efektif dan tercapai.

2. Implementasi. Tahap implementasi terdiri dari 3 (tiga) langkah utama yaitu:

a. Sosialisasi

Pada tahapan ini merupakan tahapan untuk memperkenalkan kepada seluruh komponen perusahaan tentang aspek yang memiliki kaitan dengan implementasi CSR khususnya tentang pedoman CSR yang telah dibuat. Pada tahapan sosialisasi dirasa perlu untuk membuat sebuah tim khusus yang langsung diawasi oleh direktur agar sosialisasi bersifat efektif. Tujuan dari sosialisasi ini adalah untuk mendapatkan dukungan dari seluruh komponen perusahaan agar nantinya tidak ada kendala pada saat implementasi nantinya.

b. Pelaksanaan

Didalam tahapan implementasi atau pelaksanaan nantinya juga harus sesuai dengan pedoman CSR serta pedoman perusahaan yang telah disusun sebelumnya. Hal ini tentunya bertujuan agar dalam proses implementasi sebuah CSR, sebuah perusahaan dapat melaksanakannya dengan maksimal.

c. Internalisasi.

Didalam tahapan internalisasi berisi tentang upaya yang dilakukan untuk mengenalkan CSR kepada seluruh proses bisnis yang dimiliki perusahaan. Berbeda dengan sosialisasi, tahapan ini merupakan tahapan jangka panjang yang bertujuan agar penerapan CSR nantinya tidak hanya sekedar untuk pemenuhan compliance namun sudah beyond compliance.

3. Evaluasi

Setelah beberapa tahapan telah dilakukan, maka tahapan selanjutnya adalah tahap evaluasi. Didalam tahap ini bertujuan untuk mengetahui tentang proses penerapan program CSR yang telah dijalankan. Dalam penerapannya, tahap evaluasi harus dilakukan dari waktu ke waktu agar pengukuran keefektivitasan program dapat berhasil. Tahap evaluasi juga semestinya tetap dilakukan dengan tidak bergantung pada kegagalan ataupun keberhasilan sebuah program. Hal ini dikarenakan evaluasi merupakan tahap yang digunakan untuk mengetahui apakah sebuah program dikatakan gagal atau bahkan berhasil.

Tahap evaluasi dilakukan untuk mempermudah perusahaan dalam mengambil sebuah keputusan. 
Perusahaan nantinya mampu memutuskan untuk menghentikan, memperbaiki, melanjutkan serta melakukan pengembangan dalam beberapa aspek yang telah diimplementasikan perusahaan pada program CSR. Untuk melakukan tahap evaluasi, perusahaan dapat meminta pihak yang bersifat independen untuk mengaudit program CSR yang telah dilakukan. Sementara itu untuk evaluasi dengan bentuk assessment audit atau scoring juga bisa dilakukan secara mandatory. Tahap evaluasi ini pada akhirnya akan membantu perusahaan untuk kembali memetakan situasi, kondisi perusahaan, serta pencapaian perusahaan ketika melakukan implementasi CSR melalui sebuah rekomendasi.

4. Pelaporan

Pelaporan perlu dilakukan untuk membangun sistem informasi, baik untuk keperluan proses pengambilan keputusan maupun keperluan keterbukaan informasi material dan relevan mengenai perusahaan. Tujuan diadakannya pelaporan adalah untuk membangun sebuah sistem informasi yang baik di dalam sebuah perusahaan. Informasi tersebut nantinya digunakan untuk menunjang keperluan dalam hal pengambilan keputusan serta untuk dilaporkan kepada stakeholder (pemangku kepentingan).

\section{METODE PENELITIAN}

Penyelidikan ini menggunakan pendekatan kualitatif, untuk memahami makna individu atau kumpulan dalam masalah sosial atau masalah manusia (Creswell, 2009:33). Proses dari penyelidikan meliputi pertanyaan-pertanyaan, dan prosedur. Bentuk penelitian ini menggunakan studi kasus. Menurut Idrus (2009:57) studi kasus adalah suatu penyelidikan intensif tentang seorang individu, namun studi kasus terkadang dapat juga dipergunakan untuk menyelidiki unit sosial yang kecil seperti keluarga, sekolah, kelompok-kelompok "geng" anak muda. Studi kasus sebagai penyelidikan yang rinci atas suatu latar atau peristiwa tertentu. Dalam pendekatan studi kasus, peneliti menyelidiki satu individu atau unit sosial tertentu secara lebih mendalam.

Data penelitian dikumpulkan melalui wawancara dan studi dokumen. Wawancara mendalam dilakukan untuk menggali informasi kepada Community Development Officer (CDO), CSR Coordinator, tokoh masyarakat setempat, dan masyarakat lokal penerima manfaat CSR. Studi dokumen dibutuhkan sebagai data sekunder, diperoleh dari berbagai sumber dokumen antara lain Laporan CSR PT Pertamina RU II Pakning, berita-berita surat kabar mengenai CSR dan website perusahaan. Data yang diperoleh dianalisis dengan model analisis interaktif. Model ini terdiri dari tiga komponen analisis yaitu: reduksi data, sajian data dan penarikan kesimpulan (Miles dan Huberman, 2014).

\section{HASIL DAN PEMBAHASAN}

Program Konservasi dan Revitalisasi Permata Hijau merupakan program berbasis lingkungan yang dilakukan oleh CSR PT Pertamina RU II Sungai Pakning. Fokus dalam Program Konservasi dan Revitalisasi Permata Hijau diwujudkan dengan kegiatan konservasi lingkungan, yaitu kawasan mangrove yang semakin memburuk dan lahan yang terdegradasi. Program ini juga memiliki kegiatan lain seperti budidaya ikan nila air payau dan pengolahan produk guna untuk meningkatkan kesejahteraan masyarakat. Program Konservasi dan Revitalisasi Permata Hijau juga merupakan program pelestarian lingkungan yang berbasis pada pemberdayaan masyarakat yaitu infrastructure, capacity building dan community empowerment.

Sebagai salah satu badan usaha milik negara (BUMN) yang ada di Indonesia, PT Pertamina RU II Sungai Pakning diwajibkan menjalankan peraturan yang berlaku. salah satunya adalah peraturan terkait pelaksanaan tanggung jawab sosial perusahaan atau CSR yang tertera dalam Undang-Undang nomor 40 tahun 2007 pasal 74 dan Peraturan Pemerintah no 47 tahun 2012. Pelaksanaan program CSR juga bentuk ketaatan perusahaan terhadap aturan negara dan panduan berskala global seperti ISO 26000 mengenai pelaksanaan CSR. CSR PT Pertamina RU II Sungai Pakning dilaksanakan bukan hanya sebagai pemenuhan kewajiban perusahaan terhadap undang-undang, namun juga untuk mengatasi permasalahan lingkungan dan sosial masyarakat. Selain itu, melalui program ini perusahaan juga ingin mengubah perilaku masyarakat agar dapat menjaga kelestarian lingkungan. Pihak CSR PT Pertamina RU II Sungai Pakning juga menambahkan kegiatan CSR tersebut dilaksanakan melalui program Konservasi dan Revitalisasi Mangrove Permata Hijau.

Tujuan dari Program Konservasi dan Revitalisasi Mangrove Permata Hijau tersebut sesuai dengan konsep Corporate Social Responsibility (CSR) yang telah disampaikan Rudito dan Famiola (2013) yaitu konsep tersebut menjelaskan bahwa CSR membuat perusahaan dapat berinteraksi dengan komunitas lokal dan beradaptasi guna untuk mendapatkan relasi dan keuntungan sosial. Dalam hal ini, PT Pertamina RU II Sungai Pakning memerlukan penerimaan masyarakat sekitar yang terkena dampak operasional perusahaan. Dampak yang diakibatkan oleh aktivitas perusahaan dapat merugikan masyarakat mulai dari polusi, limbah, serta infrastruktur. Oleh karena itu, program CSR merupakan jalan untuk mendapatkan social licence to operate atau lisensi sosial agar bisa tetap beroperasi dengan lancar dan tetap memiliki relasi yang baik dengan masyarakat setempat.

"CSR itu merupakan Tanggung Jawab Perusahaan. Sungai Pakning secara geografis kan di pesisir dan abrasi tinggi, juga dilihat dari hasil Sosmap bahwa kesejahteraan masyarakat disana masih rendah. Tujuan utama untuk meningkatkan kesadaran masyarakat, mengatasi abrasi dan meningkatkan kesejahteraan masyarakat " 
(Community Development Facilitator, wawancara pribadi, 2 Desember 2019).

Konsep CSR sebagaimana yang dijelaskan oleh Rusdianto (2013) merupakan organisasi adalah sebuah entitas usaha yang wajib melakukan adaptasi kultural dengan lingkungannya, yang mana konsep ini memberikan cara bagi perusahaan untuk melibatkan diri dan memberikan perhatian terhadap dampak sosial yang ada juga komitmen perusahaan untuk terus menerus bertindak secara etis, beroperasi secara legal dan berkontribusi untuk peningkatan ekonomi bersamaan dengan peningkatan kualitas hidup komunikas lokal dan masyarakat lebih luas. Program Konservasi dan Revitalisasi Mangrove Permata Hijau dilaksanakan atas dasar kepedulian lingkungan, yang mana kerusakan lingkungan di daerah Ring 2 terdampak operasional perusahaan yaitu Desa Pangkalan Jambi oleh faktor alam dan perilaku manusia dalam menyebabkan rusaknya ekosistem mangrove dan abrasi lahan.

"Di wilayah terdampak operasional pertamina terdapat masalah abrasi di pesisir pantai desa pangkalan jambi, terjadi puluhan tahun lebih dari 200 meter. Karena wilayah itu termasuk dalam wilayah binaan Pertamina, maka Pertamina melakukan langkah-langkah partisipatif perencanaan bersama masyarakat lokal untuk memetakan masalah, kebutuhan, dan modal. Ditemukan kebutuhan paling mendasar masyarakat adalah penanganan abrasi, berdasarkan hasil FGD desa itu telah bergeser 300 meter dari desa awal mereka dan akan menjadi ancaman jika abrasi tidak diselesaikan. Kemudian dipetakan kembali alasan abrasi terjadi, karena human error yaitu penebangan Mangrove ilegal untuk keperluan pembangunan dan secara natural gelombang ombak selat bengkalis itu relatif tinggi pasang surutnya" (Community Development Specialist, wawancara pribadi, 2 Desember 2019).

Dampak yang didapatkan masyarakat melalui permasalahan ini adalah masyarakat Desa Pangkalan Jambi harus relokasi dari permukiman hingga ke 300 meter dari lokasi permukiman sebelumnya. Dalam hal ini, Program Konservasi dan Revitalisasi Mangrove Permata Hijau melibatkan diri ke dalam isu yang dihadapi masyarakat dan berkontribusi dalam penanganan isu tersebut dengan adanya kegiatan konservasi dan revitalisasi mangrove, serta pelatihan untuk meningkatkan kapasitas masyarakat dalam menjaga ekosistem Mangrove. Selain itu, program CSR PT Pertamina RU II Sungai Pakning juga memfokuskan ke peningkatan kesejahteraan masyarakat yang mana sesuai dengan konsep Triple Bottom Line (TBL).

Konsep TBL menitikberatkan bahwa keberadaan perusahaan haruslah meningkatkan kualitas lingkungan sekitarnya (Planet), meningkatkan kesejahteraan masyarakat sekitar (People), dalam menjalankan aktivitas perusahaan untuk meraih keuntungan (Profit). Program CSR yang digagas oleh PT Pertamina RU II Sungai Pakning tidak hanya melakukan konservasi lingkungan, namun juga memberdayakan masyarakat untuk dapat lebih kuat secara ekonomi. Program ini melibatkan kelompok masyarakat untuk berpartisipasi dalam menggagas rancangan kegiatan program sesuai dengan kebutuhan mereka. Atas dasar kebutuhan masyarakat terkait penyelesaian isu abrasi dan peningkatan kesejahteraan masyarakat, PT Pertamina RU II Sungai Pakning melaksanakan Program Konservasi dan Revitalisasi Mangrove Permata Hijau dengan Kelompok Harapan Bersama sebagai penerima manfaat dan terdapat tiga kelompok kerja (Pokja) dalam kelompok tersebut yaitu Pokja Mangrove, Pokja Budidaya Ikan, serta Pokja Pengolahan.

Beberapa manfaat yang didapatkan PT Pertamina RU II Sungai Pakning melalui program CSR selaras dengan apa yang disampaikan Wibisono (2007). Menurut Wibisono, beberapa manfaat yang didapatkan oleh sebuah perusahaan dari adanya CSR adalah dari segi sosial, ekonomi, hingga dari segi prestasi atau penghargaan. Dari segi sosial, perusahaan mendapatkan kepercayaan dan relasi yang baik dengan masyarakat sebagai perusahaan yang peduli terhadap lingkungan dan masyarakat setempat. Dari segi ekonomi, perusahaan tidak merasakan manfaatnya secara langsung karena pada program CSR pihak perusahaan mengeluarkan dana yang cukup besar. Namun, keuntungan tidak langsung dapat dilihat melalui relasi baik yang dimiliki perusahaan dengan masyarakat sehingga operasional perusahaan berjalan lancar dan dapat menghasilkan produk untuk keperluan bisnis perusahaan. Manfaat berikutnya dari segi prestasi, yaitu Program Konservasi dan Revitalisasi Mangrove Permata Hijau ini berhasil menerima banyak penghargaan nasional seperti PROPER Emas 2018, UNS SME AWARD, hingga penghargaan ISDA 2018 yang mana program ini telah berkontribusi terhadap SDGs poin 14 mengenai pelestarian ekosistem laut.

Tahap awareness building sebuah tahap awal yang bertujuan untuk membangun kesadaran tentang pentingnya program CSR yang akan dilakukan. Pada tahapan ini, peneliti menganalisis bahwa PT Pertamina RU II Sungai Pakning telah sesuai dengan konsep yang disampaikan. Hal ini dikarenakan, awareness building terkait Program Konservasi dan Revitalisasi Mangrove Permata Hijau dapat menyebar secara luas kedalam internal Departemen CSR sebagai penyelenggara utama. Awareness building dilakukan sesuai dengan tahapan CSR menurut Wibisono (2007) yaitu tidak hanya dilakukan di perusahaan, namun juga kepada masyarakat dan stakeholder untuk memberikan saran dan kritik terhadap program yang akan dilakukan masyarakat. Oleh karena itu, pihak masyarakat juga merasakan awareness terkait penting nya Program Konservasi dan Revitalisasi Mangrove Permata Hijau karena telah dilibatkan dari awal perencanaan program.

CSR Assessment. CSR assessment ini merupakan tahapan yang dilakukan untuk memetakan kondisi perusahaan saat menyelenggarakan CSR. Pemetaan ini berisi tentang hal penting yang harus ada di dalam CSR baik konsep maupun 
kebutuhan dari CSR tersebut. Program Konservasi dan Revitalisasi Mangrove Permata Hijau sesuai dengan tahapan CSR assessment yaitu dengan diadakannya social mapping, FGD, dan rapat program karena melalui proses tersebut perusahaan dapat memetakan aspek-aspek penting dalam program CSR tersebut, konsep, hingga detail kegiatan dan anggaran.

CSR Manual Building. Tahap ini merupakan tahap inti dari sebuah perencanaan. Hal ini dikarenakan pada tahapan ini pihak penyelenggara CSR akan membuat sebuah acuan yang akan digunakan pada saat pelaksanaan CSR. Program Konservasi dan Revitalisasi Mangrove Permata Hijau telah memenuhi aspek ini dibuktikan dengan adanya indikator pelaksanaan, Renstra, Renja, ToR, Matriks, dan pembagian jobdesk dalam pelaksanaan program CSR ini.

"Community Development Specialist bertugas melakukan analisa dan merancang program, memetakan masalah. Community Development Facilitator bertugas memfasilitasi dan menjembatani program yang disusun untuk disampaikan ke masyarakat melalui diskusi, kunjungan rutin, dan komunikasi non formal. Community Development Data \& Analyst bertugas mengukur kinerja dari pelaksanaan kegiatan CSR. Community Development Media and Publication, menginformasikan dan mempublikasikan kegiatan ke stakeholder terutama media massa dan elektronik" (Community Development Specialist, wawancara pribadi, 2 Desember 2019)

Adanya pelaksanaan FGD dan sosialisasi program menjadi sebuah bukti bahwa proses sosialisasi telah dipenuhi. Dalam program CSR, Perusahaan melakukan pendekatan kepada pemuka pendapat untuk melakukan FGD bersama masyarakat merupakan hal yang tepat. Di Provinsi Riau, tepatnya Kecamatan Bukit Batu, Kabupaten Bengkalis kearifan lokal berasal dari tradisi yang dipertahankan masyarakat sejak pemerintahan Kerajaan Siak. Kerajaan Siak merupakan kerajaan Melayu-Islam yang menguasai daerah dari Riau daratan hingga Malaka. Oleh karena itu, masyarakat Desa Pangkalan Jambi memiliki adat istiadat yang dijaga secara turun temurun.

Tradisi yang ditinggalkan oleh penguasa perairan Riau-Malaka yaitu Laksmana Raja Dilaut mengajarkan untuk menerapkan ajaran Islam dalam setiap kegiatan yang mana masyarakat Desa Pangkalan Jambi menerapkan tradisi ini terhadap semua kegiatan baru dengan tujuan untuk meminta keselamatan dan dijauhkan dari malapetaka. Dalam melaksanakan sosialisasi, PT Pertamina RU II Sungai Pakning melakukan adaptasi kultural dengan mengikuti kegiatan masyarakat.

Masyarakat Desa Pangkalan Jambi yang berprofesi sebagai nelayan memiliki tradisi untuk melakukan doa bersama saat kapal baru akan berlayar. Tokoh Masyarakat Nelayan desa Pangkalan Jambi menjelaskan bahwa tradisi ini terdiri dari doa bersama yang akan dipimpin oleh tokoh agama, kemudian penurunan kapal serta makan bersama. Tradisi masyarakat melayu memiliki kekuatan, di mana keberadaan Lembaga Adat Melayu (LAM) memiliki peran dalam melindungi kelestarian budaya tersebut. Masyarakat pendatang baik dari etnis jawa, batak, maupun tionghoa tetap harus mengikuti tradisi ini.

Begitu juga dengan pihak perusahaan, PT Pertamina RU II Sungai Pakning yang mayoritas personel nya merupakan pendatang tetap harus mengikuti tradisi ini. Pihak perusahaan menggunakan kearifan lokal ini sebagai salah satu media untuk bisa masuk dan berkomunikasi dengan kelompok masyarakat. Melalui kegiatan ini, pihak perusahaan dapat membangun relasi dengan masyarakat dan mengkomunikasikan pesan CSR. Masyarakat melayu memiliki karakteristik gotong royong dan seorang opinion leader seperti tokoh masyarakat dan tokoh agama memiliki kekuatan secara sosial untuk menggerakkan masyarakat. Pihak perusahaan mengkomunikasikan pesan CSR kepada opinion leader dan masyarakat lainnya, yaitu Ketua Kelompok Nelayan yang akhirnya mengajak masyarakat lain untuk berpartisipasi dalam program ini. Dalam proses ini, terdapat komunikasi dua arah antara pihak perusahaan dan penerima manfaat program. Cara sosialisasi perusahaan kepada masyarakat juga termasuk dalam outsourcing dikarenakan pihak yang mengkomunikasikan ke masyarakat desa adalah opinion leader.

Penerimaan program Konservasi dan Revitalisasi Mangrove Permata Hijau juga dipengaruhi aspek kearifan lokal yang mana laut merupakan tempat yang sakral bagi masyarakat nelayan melayu dan harus dijaga. Pesan ini juga memberikan pengaruh terhadap kesuksesan sosialisasi dan penerimaan masyarakat lokal terhadap pelaksanaan program CSR dikarenakan fokus pelaksanaan program ini sesuai dengan kepercayaan masyarakat untuk menjaga ekosistem laut. Serta nilai gotong royong yang dianut masyarakat melayu sehingga program ini dilakukan secara gotong royong bersama masyarakat.

Pada pelaksanaannya, program CSR arus sesuai dengan pedoman atau acuan yang mereka buat pada saat rapat panitia. Pembuatan pedoman ini tentunya merupakan langkah yang tepat karena dapat menjadi petunjuk saat pelaksanaan Program Konservasi dan Revitalisasi Mangrove Permata Hijau. Sebelum implementasi, program ini membentuk kelompok binaan CSR yaitu Kelompok Harapan Bersama. Kelompok Nelayan Harapan Bersama telah terbentuk pada tahun 2004, namun pada saat itu kelompok hanya merupakan sebuah paguyuban nelayan dan belum memiliki pengetahuan mengenai pelestarian ekosistem laut. Kelompok Nelayan Harapan Bersama akhirnya menjadi kelompok binaan CSR PT Pertamina RU II Sungai Pakning pada tahun 2017 dengan terbentuknya 3 unit kelompok kerja beranggotakan 41 orang masyarakat desa Pangkalan Jambi.

"Kelompok Mangrove Harapan Bersama dengan beberapa kelompok kerja (Pojka) di dalamnya. Pokja 
Mangrove yang mengurus pembibitan dan kelestarian Mangrove, kemudian Pokja Budidaya Ikan bertanggung jawab dalam Budidaya Ikan Nila Payau, dan Pokja Pengolahan yang bertanggung jawab pengolahan produk hasil laut dan Mangrove” (Community Development Specialist, wawancara pribadi, 2 Desember 2019).

Program kegiatan yang dilaksanakan dalam Program Konservasi dan Revitalisasi Mangrove Permata Hijau ini berupa konservasi dan revitalisasi kawasan Mangrove, budidaya ikan nila air payau, serta pengolahan produk yang sesuai dengan kepentingan masyarakat nelayan melayu untuk menjaga ekosistem laut. Implementasi program dilakukan melalui pelatihan, pendampingan, pembangunan infrastruktur serta bantuan keperluan program.

"Kami mendapat pelatihan, dari Universitas Diponegoro tentang teknologi hybrid engineering, terus teknik membibit Mangrove dan menanam Mangrove. Alhamdulillah sekarang Mangrove sudah mulai tumbuh di pesisir Desa Pangkalan Jambi. Sekarang kami mampu melakukan pembibitan dan penanaman sendiri, bahkan menjual bibit Mangrove untuk keperluan penanaman" (Ketua Kelompok Harapan Bersama, wawancara pribadi, 3 Desember 2019)

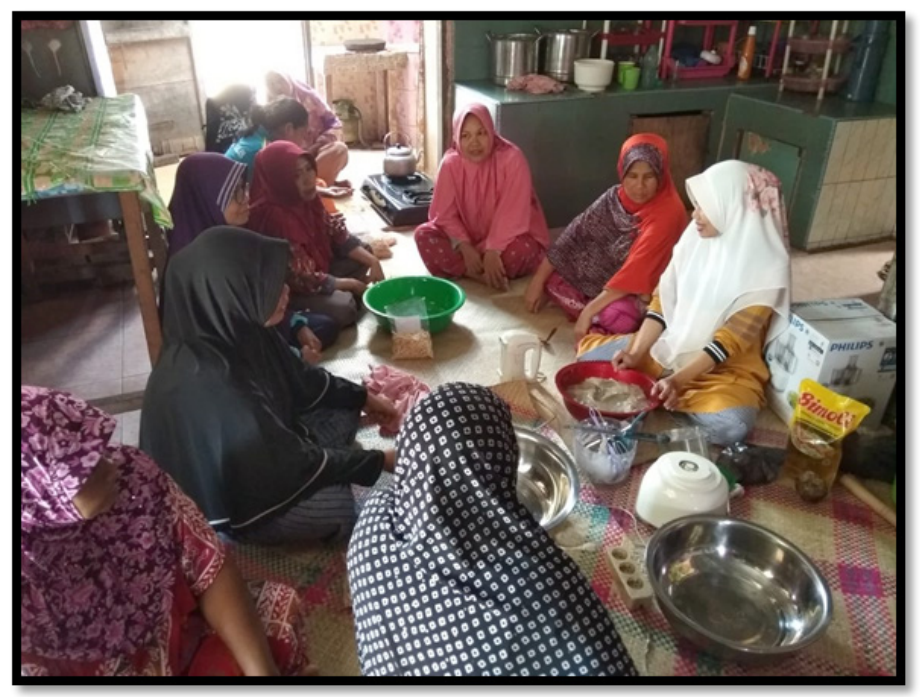

Gambar 2. Pelatihan Pembuatan Produk Olahan

Narasumber menambahkan,

"Kalau di pokja pengolahan, pelatihan pembuatan produk olahan Mangrove dan hasil laut. Ada pelatihan pembuatan kerupuk, pelatihan pembuatan amplang, dan selain itu banyak terdapat produk hasil inovasi dari anggota kelompok. Sekarang produknya kami udah banyak dan dikemas dengan bagus serta ada PIRT, label MUI juga bantuan alat-alat memasak dan rumah produksi” (Anggota Kelompok Harapan Bersama, wawancara pribadi, 3 Desember 2019)

Pada langkah yang ketiga atau internalisasi ke seluruh bagian di PT Pertamina RU II Sungai Pakning. Internalisasi sendiri merupakan kegiatan jangka panjang untuk mengenalkan tentang pentingnya CSR dalam perusahaan. Internalisasi juga bertujuan agar CSR tersebut dapat berlanjut.

Tahap selanjutnya yang dilakukan oleh PT Pertamina RU II Sungai Pakning adalah tahap evaluasi. Evaluasi bertujuan untuk mengetahui tentang sejauh mana sebuah program sudah berjalan. Dalam pelaksanaanya, tahap evaluasi tentunya harus dilakukan secara bertahap agar keefektifan program dapat terukur. Tahapan-tahapan dalam program CSR yang dilakukan oleh PT Pertamina RU II Sungai Pakning sesuai dengan tahapan CSR menurut Wibisono yaitu Awareness Building, CSR Assesment, dan CSR Manual Building. Program yang dilaksanakan juga bertujuan untuk meningkatkan kesadaran masyarakat terhadap lingkungan hidup dan sekaligus meningkatkan kesejahteraan masyarakat melalui pemberdayaan masyarakat sesuai dengan tujuan CSR menurut Robbins and Coulter (2010).

Dalam tahapan evaluasi yang dilakukan oleh PT Pertamina RU II Sungai Pakning, tim CSR menggunakan 11 aspek Indeks Kepuasan Masyarakat yaitu Sosialisasi Program, Perencanaan Program, Proses Pelaksanaan Program, Kesesuaian Biaya Program, Jadwal Pelaksanaan Program, Sarana dan Prasarana Program, Fasilitator Program, Pemanfaatan Program, Dampak Ekonomi Program, Dampak Sosial Program, dan Dampak Lingkungan Program. Namun, evaluasi terkait keanekaragaman hayati tidak dilakukan oleh pihak perusahaan sehingga PT Pertamina RU II Sungai Pakning bekerja sama dengan Institut Pertanian Bogor (IPB) untuk melakukan Evaluasi Keanekaragaman Hayati. Melalui IKM tersebut, dapat dilihat capaian program dari banyak aspek dan menjadi pembelajaran yang baik untuk pelaksanaan program CSR berikutnya.

Pengukuran IKM dilakukan menggunakan kuesioner dan wawancara kepada masyarakat penerima manfaat. Hal yang menjadi nilai tambah bagi evaluasi Program Konservasi dan Revitalisasi Mangrove Permata Hijau adalah 
masyarakat tetap terlibat dalam proses evaluasi yang mana pihak perusahaan melakukan evaluasi program dengan melibatkan masyarakat penerima manfaat sebagai informannya. Hasilnya berguna sebagai feedback bagi perusahaan pengembangan konsep dan pelaksanaan program CSR.

\section{KESIMPULAN}

Program Konservasi dan Revitalisasi Mangrove Permata Hijau PT Pertamina RU II Sungai Pakning merupakan program CSR pelestarian lingkungan yang berbasis pada pemberdayaan masyarakat (community development) yang dilaksanakan melalui adaptasi kultural kearifan lokal yaitu adat melayu dan dilakukan dengan pihak internal maupun eksternal. CSR dilaksanakan melalui Pokja Mangrove, Pokja Budidaya Ikan, serta Pokja Pengolahan. Tahapan implementasi Program Konservasi dan Revitalisasi Mangrove Permata Hijau terbagi dalam beberapa langkah yaitu planning, implementasi, evaluasi, serta pelaporan CSR. Program berfokus pada usaha pelestarian lingkungan, serta peningkatan kapasitas masyarakat dalam mengelola lingkungan dan meningkatkan kesejahteraan ekonomi masyarakat. Komunikasi dua arah antara perusahaan dan stakeholders yang terlibat (masyarakat lokal, tokoh-tokoh masyarakat, LSM dan pemerintah lokal) yang dilakukan dalam pelaksanaan program CSR ini yang menjadi kunci utama kelancaran program CSR PT Pertamina RU II Pakning.

\section{DAFTAR PUSTAKA}

[1] Creswell, J.W. (2009). Research Design, Qualitative, Quantitative, and Mixed Methods Approaches. Thousand Oaks, California USA: Sage Publications.

[2] Daft, R.L. (2016). Management (12th Ed). Publisher Cengage Learning

[3] Donaldson, T., and Preston, L.E. (1995), The stakeholder theory of the corporation: concepts, evidence, and implications. Academy of Management Review, 20(1), p. 65-91.

[4] Freeman, R.E. (1984). Strategic management: A stakeholder approach. Boston, USA: Pitman. ISBN 0-273-01913-9.

[5] Grunig, James E and Todd Hunt. (1984). Managing Public relations. Chicago: Holt. Rinehart and Winston, Inc.

[6] Hadi, Nor. (2014). Corporate Social Responsibility. Yogyakarta, Indonesia: Graha Ilmu

[7] Idrus, M. (2009). Metode penelitian ilmu sosial: Pendekatan kualitatif dan kuantitatif. Yogyakarta, Indonesia: Erlangga

[8] Idrus, M. (2009). Metode Penelitian Ilmu Sosial: Pendekatan Kualitatif dan Kuantitatif. 2th Ed. Jakarta: Erlangga

[9] Kehati. (n.d.). http://www.kehati.or.id

[10] Lamarche T, Bodet C. Does CSR Contribute to Sustainable Development? What a Régulation Approach Can Tell Us. Review of Radical Political Economics. 2018;50(1):154-172. DOI:10.1177/0486613416635038

[11] Lo, S., \& Sheu, H. (2007). Is corporate sustainability a value-increasing? Corporate Governance: An International Review, 15, p. 345-358.

[12] Miles and Huberman (2014). Qualitative Data Analysis: A Methods Sourcebook, 3rd Ed, Sage Publications: Los Angeles, London, New Delhi, Singapore, and Washington DC

[13] Mostardeiro, M., \& Duarte, F. (2007) CSR Strategy Formulation: A Multiple Case Study from Brazil. Social Responsibility Journal. 3 (1), pp 59-67.

[14] Moleong, Lexy J. (2007). Metodologi Penelitian Kualitatif. Penerbit PT Remaja Rosdakarya Offset, Bandung.

[15] Nurjannah, N., Suwatno, S., \& Damayanti, W. (2017). Komunikasi Corporate Social Responsibility pada Official Website Perusahaan Badan Usaha Milik Negara. Jurnal ASPIKOM, 3(2), 311-325.

[16] Pertamina. (n.d.). Pertamina https://www.pertamina.com

[17] Rudito, Bambang dan Famiola, M. (2013). Corporate Social Responsibility. Bandung: Rekayasa Sains.

[18] Rusdianto, Ujang. (2013). CSR Communication a Framework for PR. Practitioners. Yogyakarta: Graha Ilmu.

[19] Robbins, S.P., \& Coulter, M.C. (2010). Manajemen. Edisi Kesepuluh. Jakarta: Erlangga

[20] Rosilawati, Yeni dan Mulawarman, K. (2019). Kearifan Lokal Tri Hita Karana dalam Program Corporate Social Responsibility. Jurnal Aspikom, Volume 3 No 6, Januari 2019, 1215-1227

[21] Rosilawati, Yeni and Ahmad, J. (2019) Local wisdom and Stakeholder engagement for corporate social responsibility (CSR) initiatives in Indonesia, Opcion Journal, Vol. 35, No 21, pp. 205-220

[22] Salim, Mufid. (2018). Improving Organizational Attractiveness in the Job Choice by Communicating CSR Practices. Jurnal Komunikasi ISKI, Vol. 03 (02), 2018. 76-83 http://dx.doi.org/10.25008/jkiski.v3i2.226

[23] Silberhorn, D. and Warren, R.C. (2007), "Defining corporate social responsibility: A view from big companies in Germany and the UK”, European Business Review, Vol. 19 No. 5, pp. 352-372.

[24] Untung, Budi. (2008). Corporate social responsibility. Jakarta: Sinar Grafika 
[25] Wibisono, Yusuf. (2007). Membedah Konsep \& Aplikasi CSR. PT Gramedia, Jakarta.

[26] WBCSD. (n.d). World Business Council for Sustainable Development. http://www.wbcsd.org/work-program/ businessrole/previouswork/corporate-socialresponsibility.aspx 